\title{
Population morphometric variation of the endemic freshwater killifish, Fundulus lima (Teleostei: Fundulidae), and its coastal relative $F$. parvipinnis from the Baja California Peninsula, Mexico
}

\author{
Claudia Alejandra Reyes-Valdez • Gorgonio Ruiz-Campos • \\ Faustino Camarena-Rosales • José Luis Castro-Aguirre • \\ Giacomo Bernardi
}

Received: 30 September 2010/ Accepted: 30 September 2010/Published online: 26 October 2010

(C) The Author(s) 2010. This article is published with open access at Springerlink.com

\begin{abstract}
The population morphometric variation of the endangered freshwater killifish (Fundulus lima) was evaluated and compared with that of its euryhaline coastal relatives ( $F$. parvipinnis parvipinnis and F. p. brevis) on the basis of 384 specimens from the Baja California peninsula, Mexico. Forty five standardized body distances were compared by means of discriminant function analysis (DFA). Sixteen body distances were significant to distinguish two groups of populations for F. lima: a first group represented by the Bebelamas and San Javier basins, and second group composed by the basins of San
\end{abstract}

\section{A. Reyes-Valdez ( $\bigotimes)$}

Facultad de Ciencias Marinas, Universidad Autónoma de Baja California, Ensenada, Baja California 22800, México e-mail: reyesc@uabc.edu.mx

G. Ruiz-Campos · F. Camarena-Rosales

Facultad de Ciencias, Universidad Autónoma de Baja California, Ensenada, Baja California 22800, México

G. Ruiz-Campos · F. Camarena-Rosales PMB \# 064, P.O. Box 189003, Coronado, CA 92178- 9003, USA

\section{J. L. Castro-Aguirre}

Colección Ictiológica. Centro Interdisciplinario de Ciencias Marinas, Instituto Politécnico Nacional, La Paz, Baja California Sur 23092, México

\section{G. Bernardi}

Department of Ecology and Evolutionary Biology, University of California, Santa Cruz, 100 Shaffer Rd, Santa Cruz, CA 95060, USA
Ignacio, La Purísima, San Luis, San Pedro and Las Pocitas. When all freshwater and coastal populations were compared, the southernmost population of F. lima (Las Pocitas) showed a higher morphometric similarity with the southern coastal subspecies (F. p. brevis), while another southern population (San Pedro) had an intermediate position between the freshwater and coastal forms. This study suggests the presence of five evolutionary units (three freshwater and two coastal) for the genus Fundulus in the Baja California peninsula.

Keywords Morphometry - Fundulus lima . Fundulus parvipinnis - Baja California peninsula

\section{Introduction}

The family Fundulidae belongs to the order Cyprinodontiformes, a group of freshwater and estuarine small fishes commonly referred to as killifishes, or "guayacones", of Gondwanan origin (Nelson 2006). The family is restricted to the North American continent and includes four genera and approximately 50 species (Berra 2001). Within Fundulidae, the genus Fundulus is the most diverse with 30 known species (Nelson 1994; García-Ramírez et al. 2006), most of them occur in the Atlantic drainages. However, two species are confined to the Pacific drainages (Parenti 1981, Bernardi and Powers 1995), 
the California killifish Fundulus parvipinnis Girard 1854, which is distributed along the Californian coastal province (Miller and Lea 1972) and belongs to the euryhaline marine component (Follett 1960; Castro-Aguirre 1978; Castro-Aguirre et al. 1999); and the Baja California killifish, Fundulus lima Vaillant 1894, endemic to the oases of Baja California Sur (Follett 1960; Ruiz-Campos 2000) and currently categorized in danger of extinction (Ruiz-Campos et al. 2003a). The possible ancestor of Baja California killifish is assumed to have stemmed from a euryhaline population of $F$. parvipinnis that invaded the freshwater environment and later became isolated with the hydrological conditions changes that prevailed after the late Pleistocene (Camarena-Rosales et al. 2001; Ruiz-Campos et al. 2003a; Bernardi et al. 2007).

At least two nominal subspecies of California killifish have been recognized, the northern form (F. parvipinnis parvipinnis Girard 1854) from Morro Bay, California (Miller and Lea 1972) to Laguna Ojo de Liebre, Baja California Sur (De la Cruz-Agüero et al. 1996); and the southern form (F. p. brevis Osburn and Nichols 1916) from Punta Eugenia (Bernardi and Talley 2000; Bernardi et al. 2007) to Bahía Magdalena, Baja California Sur (CamarenaRosales et al. 2001).

At the same time, Bernardi et al. (2007), based on an analysis of the sequence of the mitochondrial control region (D-loop) of continental and coastal populations of the genus Fundulus on the Baja California peninsula, determined that the two subspecies of $F$. parvipinnis plus $F$. lima appeared to form an unresolved trichotomy that separated and were isolated between 200,000 and 400,000 years ago, where each one of them represents a distinct evolutionary unit. However, Camarena-Rosales et al. (2001) proposed that the genetic separation of the two coastal subspecies resulted from a parapatric process favored by the California Current. In the case of the freshwater form, F. lima, it is inferred that all its populations were first connected and later were perhaps separated by geological and hydrographical episodes (Follett 1960), although Camarena-Rosales et al. (2001) argued, based on phylogeographical aspects, that each population might have originated individually by means of a process of radiation through discontinuous founders. If this latter process did indeed occur, each discontinuous population would be a genuine species under the concept of evolutionary species (sensu Mayden and Wood 1995).

The morphological description of $F$. lima has been exclusively based on specimens from the typical locality of San Ignacio oasis (cf. Vaillant 1894; Evermann 1908; Camarena-Rosales 1999; CamarenaRosales et al. 2001), therefore, the magnitude of its morphological variation throughout its distributional range is not known (Ruiz-Campos et al. 2003a). Recent genetic analyses for populations of $F$. lima indicated certain differences in the composition and frequency of mitochondrial DNA sequences (Bernardi et al. 2007), and haplotypes (Ruiz-Campos et al. 2008), yet lacked the additional morphological analyses necessary to fully appreciate the evolutionary picture of the group.

For the present study, we evaluated the variation of 45 linear body distances among populations of Fundulus lima through its distribution range. Additionally, we compared these same characters with those of the two euryhaline coastal subspecies (F. parvipinnis parvipinnis and F. p. brevis) in order to determine diagnostic characteristics, identification, taxonomic position and evolutionary relationships in this group.

\section{Study area}

The study area comprises the freshwater wetlands (oases) and coastal wetlands (estuaries and salt marshes) in the Pacific drainage from the Río Cantamar (Baja California) to Río Las Pocitas (Baja California Sur), Mexico (Fig. 1). The surface hydrology in the northwestern region consists of a series of small coastal streams originating on the western slope of the Sierra Juárez and Sierra San Pedro Mártir. Most of these streams become intermittent in their middle and lower courses during extremely dry conditions (Tamayo and West 1964). The mouths of most streams are blocked from the ocean by sandbars, except for extraordinary flooding events of high tides that produce riverine-estuarine conditions (Ruiz-Campos 2002). Salt marsh habitats with tidal influence are found in Todos Santos Bay (Punta Banda), San Quintín Bay, Guerrero Negro lagoon, San Ignacio lagoon, La Bocana and Magdalena Bay. The freshwater environments of the study area are represented 
Fig. 1 Studied basins for Fundulus spp. (filled circle $=F$. $p$. parvipinnis, filled square $=F$. $p$. brevis, and filled triangle $=F$. lima) in the Baja California peninsula, Mexico. (1)

Cantamar, (2) El Descanso, (3) La Misión, (4) Estero de Punta Banda, (5) San Simón, (6) Laguna de Guerrero Negro, (7) Laguna Ojo de Liebre, (8) La Bocana, (9) Laguna de San Ignacio, (10) Bahía Magdalena, (11) San Ignacio, (12) La Purísima, (13) San Javier, (14) Bebelamas, (15) San Luis [Gonzaga], (16) San Pedro [de la Presa], and (17) Las Pocitas

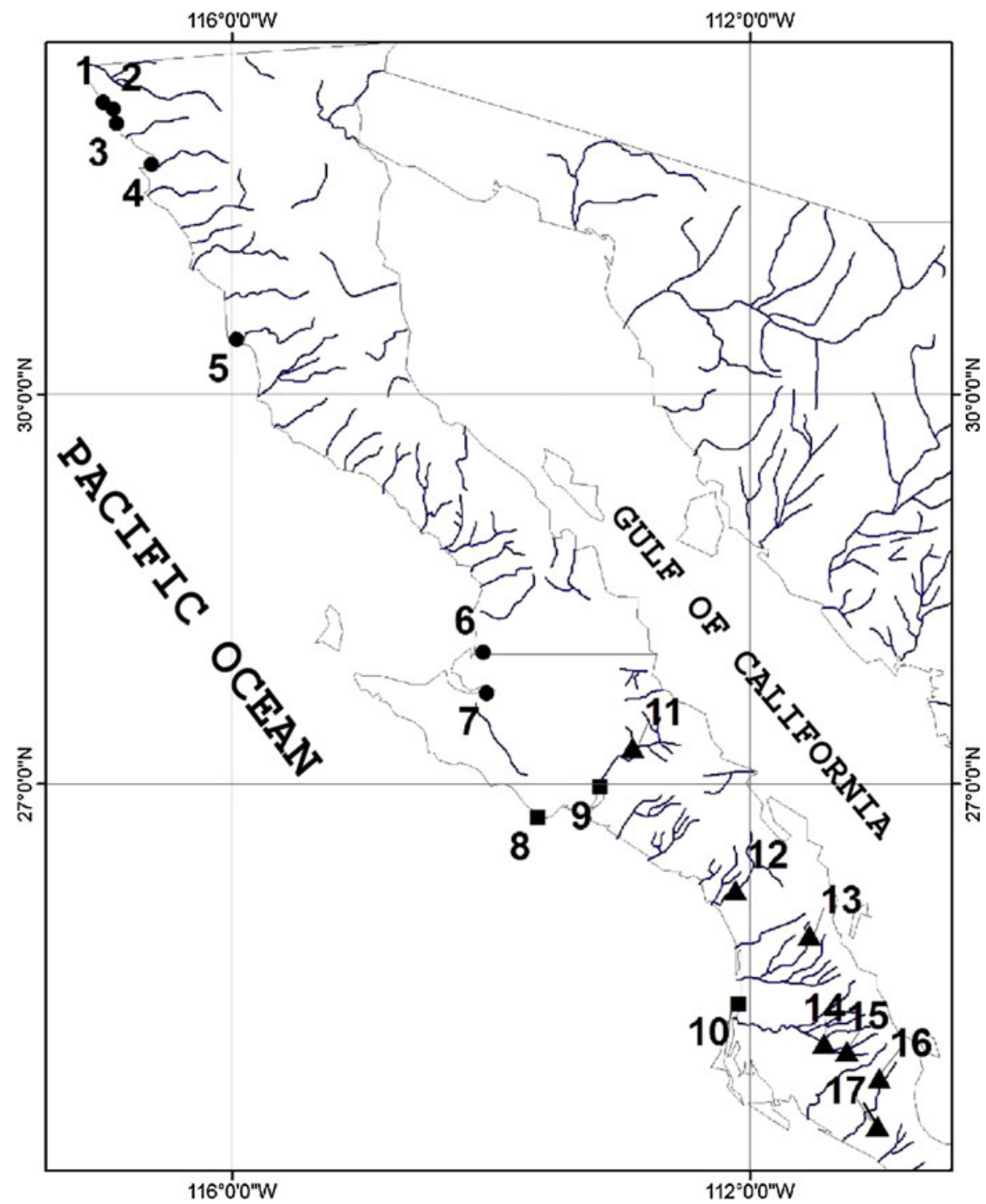

by a complex of oases through the Pacific drainage of the central and southern peninsular regions, from the Río San Ignacio to Río Las Pocitas. These oases are produced by springs that create permanent ponds within each basin and are intermittently connected during flooding events (Ruiz-Campos et al. 2003a). The vegetation of coastal saltmarshes includes Spartina foliosa, Frankenia grandifolia, Salicornia bigelovii, Distichlis spicata, Suaeda californica and Limonium californicum (Delgadillo 1992). The oases include macrophytes of the genera Typha, Potamogeton, Scirpus, Utricularia, Zannichellia, and Azolla (Wiggins 1980), as well as riparian elements such as native fan palm (Washingtonia robusta), exotic date palm (Phoenix dactylifera), common reeds (Phragmites australis) and mule's fat (Baccharis salicifolia) (Arriaga et al. 1997). The water physicochemical characteristics of the study area are described in Ruiz-Campos et al. (2003a, 2006, 2008).

\section{Methods}

The specimens of the genus Fundulus examined for this study were collected from 17 coastal and freshwater basins through the Pacific drainage of 
Fig. 2 Landmarks of morphometric distances used for the comparative analysis of the genus Fundulus from the Baja California peninsula, Mexico. a "Box truss" protocol of Bookstein et al. (1985). b Standard method of Hubbs and Lagler (1958)
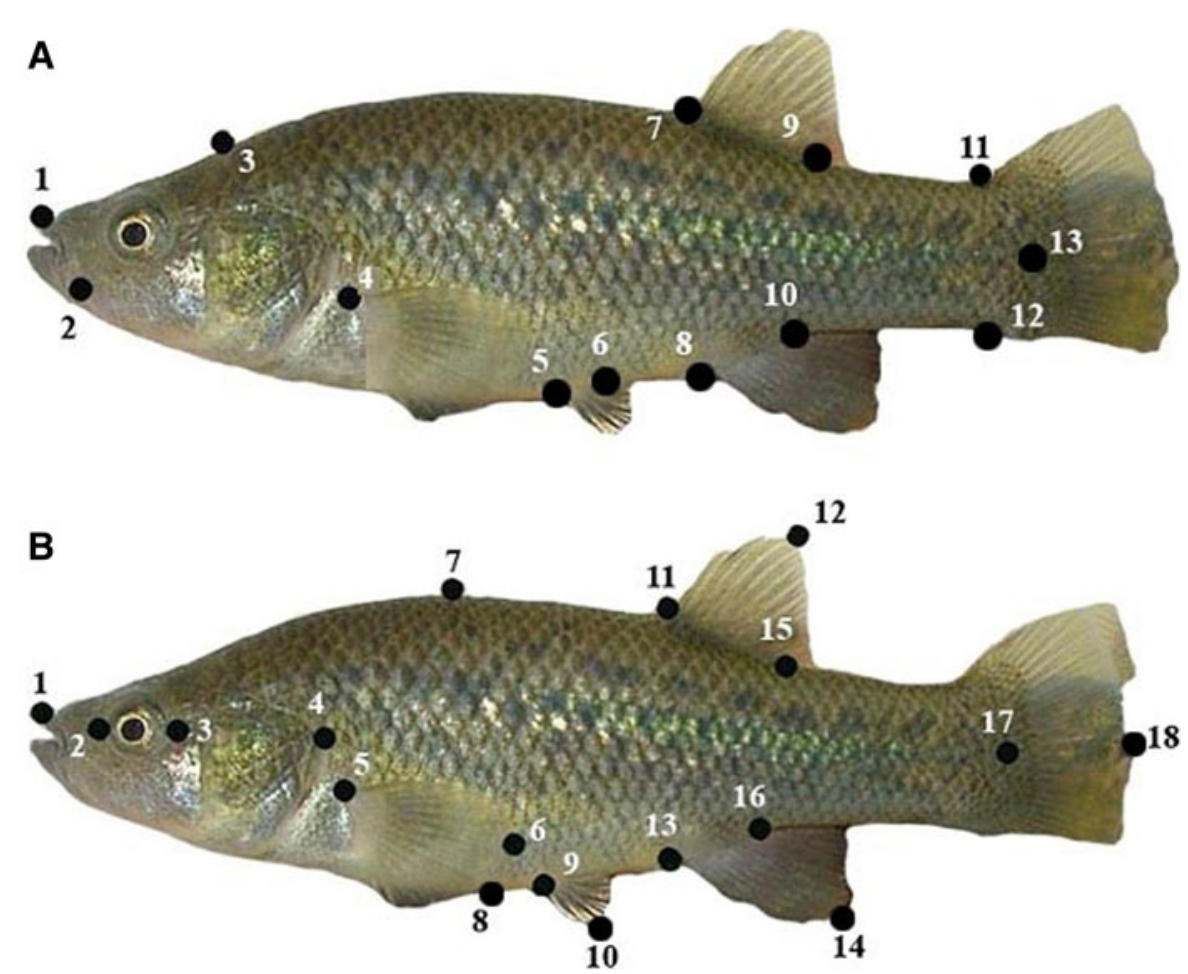

the Baja California peninsula, during 1977 to 2005 (Fig. 1). The fish specimens were deposited in the following Mexican ichthyological collections: Universidad Autónoma de Baja California (UABC) at Ensenada, Baja California; Universidad Autónoma de Nuevo León (UANL) at Monterrey, Nuevo León; and Centro Interdisciplinario de Ciencias Marinas-Instituto Politécnico Nacional-IPN (CI-CICIMAR) at La Paz, Baja California Sur.

Specimens of the species and subspecies of the genus Fundulus were selected for the morphometric analysis (cf. material examined in Appendix 1). Forty-five linear measures (M) based on box truss protocol of Bookstein et al. (1985) and the standardized method of Hubbs and Lagler (1958) were considered for the morphometric analysis of the specimens (Fig. 2a, b). All the measurements were made on the left side of each specimen using a digital caliper (precision, $0.01 \mathrm{~mm}$ ) connected to a PC. Linear measures (distances) based on box truss protocol (Fig. 2a) and traditional protocol (Fig. 2b) as well as other measures are described in Table 1.

The values of distances (body measures) were standardized by means of regression (Elliott et al.
1995) in order to remove the size component from the shape measurements (allometry) and to homogenize their variances (Jolicoeur 1963). This standardization was performed by taxon and for each character (distance) using the following equation: $\mathrm{Ms}=\mathrm{Mo}$ $(\mathrm{Ls} / \mathrm{Lo})^{\mathrm{b}}$, where $\mathrm{Ms}=$ standardized measurement, Mo = measured character length $(\mathrm{mm}), \mathrm{Ls}=$ overall (arithmetic) mean standard length $(\mathrm{mm})$ for all individuals from all populations of each species, Lo $=$ standard length $(\mathrm{mm})$ of specimen, and " $b$ " was estimated for each character from the observed data using the non-linear equation, $\mathrm{M}=\mathrm{a} \mathrm{L}^{\mathrm{b}}$. Parameter "b" was estimated as the slope of the regression of $\log$ Mo on $\log$ Lo, using every fish in every population of each taxon.

Standardized morphometric values were compared among taxa and populations by means of discriminant function using Statistica 6.0 software (StatSoft Inc., Tulsa, OK 2002). This multifactorial analysis allowed us to determine which combination of variables (distances) discriminated best among populations or taxa, and detected which populations were the most different (Elliott et al. 1995; Ruiz-Campos et al. 2003b). 
Table 1 Linear measures (distances) based on box truss protocol, traditional protocol and other measures considered in the morphometric analysis of Fundulus spp. from Baja California peninsula, Mexico

\begin{tabular}{|c|c|}
\hline Code & Morphometric character \\
\hline M1-2 & Snout tip to upper jaw tip \\
\hline M1-3 & Snout tip to occiput \\
\hline M2-3 & Upper jaw tip to occiput \\
\hline M2-4 & Upper jaw tip to pectoral fin origin \\
\hline M2-7 & Upper jaw tip to dorsal fin origin \\
\hline M2-9 & Upper jaw tip to posterior insertion of dorsal fin \\
\hline M3-4 & Occiput to pectoral fin origin \\
\hline M3-5 & Occiput to pelvic fin origin \\
\hline M3-7 & Occiput to dorsal fin origin \\
\hline M4-5 & Pectoral fin origin to pelvic fin origin \\
\hline M4-7 & Pectoral fin origin to dorsal fin origin \\
\hline M4-9 & Pectoral fin origin to posterior insertion of dorsal fin \\
\hline M5-6 & Basal length of pelvic fin \\
\hline M5-7 & Pelvic fin origin to dorsal fin origin \\
\hline M5-9 & Pelvic fin origin to posterior insertion of dorsal fin \\
\hline M6-8 & Posterior insertion of pelvic fin to anal fin origin \\
\hline M7-8 & Dorsal fin origin to anal fin origin \\
\hline M7-9 & Basal length of dorsal fin \\
\hline M7-10 & Dorsal fin origin to posterior insertion of anal fin \\
\hline M8-9 & Anal fin origin to posterior insertion of dorsal fin \\
\hline M8-10 & Basal length of anal fin \\
\hline M9-10 & Posterior insertion of dorsal fin to posterior insertion of anal fin \\
\hline M9-11 & Posterior insertion of dorsal fin to superior origin of caudal fin \\
\hline M9-12 & Posterior insertion of dorsal fin to inferior origin of caudal fin \\
\hline M10-11 & Posterior insertion of anal fin to superior origin of caudal fin \\
\hline M10-12 & Posterior insertion of anal fin to inferior origin of caudal fin \\
\hline M11-12 & Superior origin of caudal fin to inferior origin of caudal fin \\
\hline M11-13 & Superior origin of caudal fin to mid caudal base \\
\hline M12-13 & Inferior origin of caudal fin to mid caudal base \\
\hline M1-2 (2) & Preorbital length \\
\hline M1-4 (2) & Head length \\
\hline M1-11 (2) & Predorsal length \\
\hline M2-3 (2) & Eye diameter \\
\hline M3-4 (2) & Postorbital length \\
\hline M5-6 (2) & Pectoral fin length \\
\hline M7-8 (2) & Maximum depth \\
\hline M9-10 (2) & Pelvic fin length \\
\hline M11-12 (2) & Dorsal fin length \\
\hline M13-14 (2) & Anal fin length \\
\hline M15-17 (2) & Postdorsal length \\
\hline M16-17 (2) & Postanal length \\
\hline M17-18 (2) & Caudal fin length \\
\hline M1-2 (3) & Mouth width (between commisures) \\
\hline M3-4 (3) & Interorbital space \\
\hline M5-6 (3) & And head width \\
\hline
\end{tabular}




\section{Results and discussion}

The descriptive statistics (median, standard deviation and coefficient of variation) of the 45 morphometric characteristics for each one of the three taxa of Fundulus are shown in Table 2.

\subsection{Morphometric comparison among populations of Fundulus lima}

The specimens of Fundulus lima used for the morphometric analysis were grouped by hydrological basin (Fig. 3a-g). The analysis of discriminating function (ADF) indicated that 16 of the 45 characteristics examined were statistically significant $(P<0.01)$ (Table 3). The highest tolerance values $(>0.5)$ were registered for the basal length of pelvic fin (M5-6), superior origin of caudal fin to mid caudal base (M11-13) eye diameter (M2-3[2]), pelvic fin length (M9-10[2]), and caudal fin length (M17$18[(2])$. The canonical variable 1 (cv 1) accounted for $93.1 \%$ of the total variation (Table 4 ). In cv 1 , one linear characteristics exerted the greatest effect: M1-11 (2) (predorsal length, $\mathrm{Y}_{1}=0.7958$ ).

Based on squared Mahalanobis' distances $\left(\mathrm{D}^{2}\right)$, $100 \%$ of the individuals were correctly classified in their respective populations (Fig. 4). The resulting categorization of the individuals on the basis of the canonical roots 1 and 2 showed again a notable separation of the Bebelamas and San Javier basins from the remaining basins (Fig. 4).

\subsection{Morphometric comparison of Fundulus p. parvipinnis versus F.p. brevis}

In the ADF applied to compare the two subspecies of $F$. parvipinnus, seven of the 45 characteristics examined were significant $(P<0.01)$ in discriminating the two taxa: M2-9 (upper jaw tip to posterior insertion of dorsal fin); M4-7 (pectoral fin origin to dorsal fin origin), M1-4[2] (head length), M1-11[2] (predorsal length). M15-17[2] (postdorsal length), M16-17[2] (postanal length) and M17-18[2] (caudal fin length) (Table 3). The tolerance values of the characteristics ranged from 0.10 (M1-11[2], predorsal length) to 0.63 (M5-6, basal length of pelvic fin). The cv 1 accounted the $100 \%$ of the total variation (Table 4) and was associated to two lineal characters:
M2-9 (upper jaw tip to posterior insertion of dorsal fin, $\mathrm{Y}_{1}=-0.8107$ ) and M1-11[2] (predorsal length, $\left.\mathrm{Y}_{1}=-0.8121\right)$. The percentage of correct classification of individuals in the two compared subspecies was $100 \%$.

\subsection{Morphometric comparison of populations of Fundulus lima versus $F$. parvipinnis spp.}

In the ADF applied to all the populations of the genus Fundulus lima and Fundulus parvipinnis by taxa, 24 of the 45 characteristics examined turned out to be statistically significant $(P<0.01)$ : M2-4 (upper jaw tip to pectoral fin origin), M2-9 (upper jaw tip to posterior insertion of dorsal fin), M3-4 (occiput to pectoral fin origin), M4-5 (pectoral fin origin to pelvic fin origin), M5-6 (basal length of pelvic fin), M5-7 (pelvic fin origin to dorsal fin origin), M5-9 (pelvic fin origin to posterior insertion of dorsal fin), M6-8 (posterior insertion of pelvic fin to anal fin origin), M7-9 (basal length of dorsal fin), M9-10 (posterior insertion of dorsal fin to posterior insertion of anal fin), M9-12 (posterior insertion of dorsal fin to inferior origin of caudal fin), M1-2[2] (preorbital length), M1-4[2] (head length), M1-11[2] (predorsal length), M2-3[2] (eye diameter), M7-8[2] (maximum depth), M9-10[2] (pelvic fin length), M11-12[2] (dorsal fin length), M13-14[2] (anal fin length), M15-17[2] (postdorsal length), M16-17[2] (postanal length), M17-18[2] (caudal fin length), M3-4[3] (interorbital space) and head width (M5-6[3]) (Table 3).

The cv1 contributed $86.17 \%$ of the total variation (Table 4), principally correlated with two linear characteristics: M2-9 (upper jaw tip to posterior insertion of dorsal fin, $\mathrm{Y}_{1}=0.6317$ ), and M1-11[2] (predorsal length, $\mathrm{Y}_{1}=0.6439$ ).

Predictive classification of individuals in each basin and taxon showed that $100 \%$ of the individuals were correctly classified in their respective populations and taxa. Based on canonical roots 1 and 2, and according to squared Mahalanobis' distances (Fig. 5a), two population groups could be identified: the first included the freshwater populations of San Javier and Bebelamas, the second comprised both fresh water and coastal populations. In that second group, we could distinguish (1) association between the southernmost population of $F$. lima (Rio Las Pocitas basin) with the southern coastal subspecies 


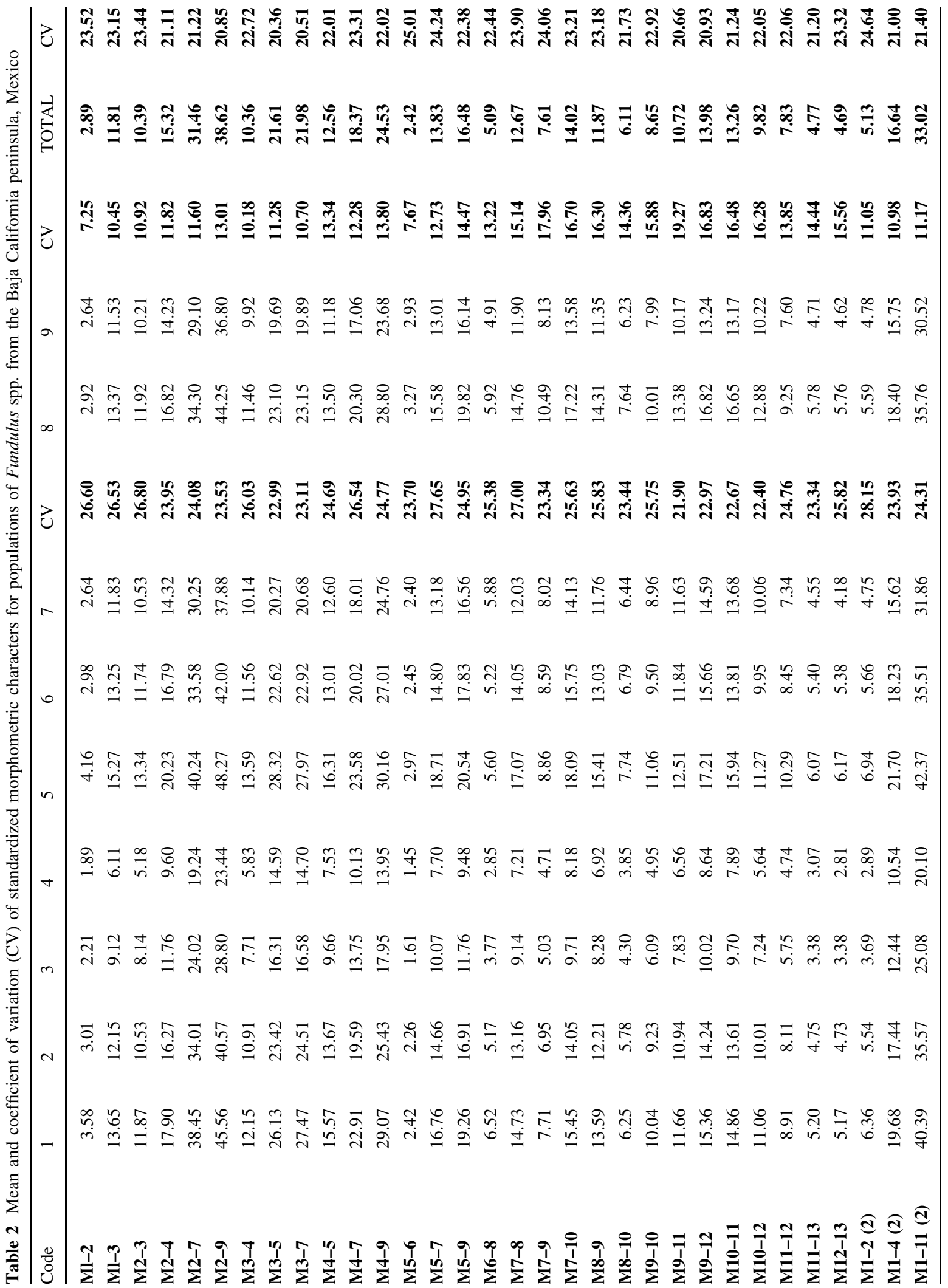




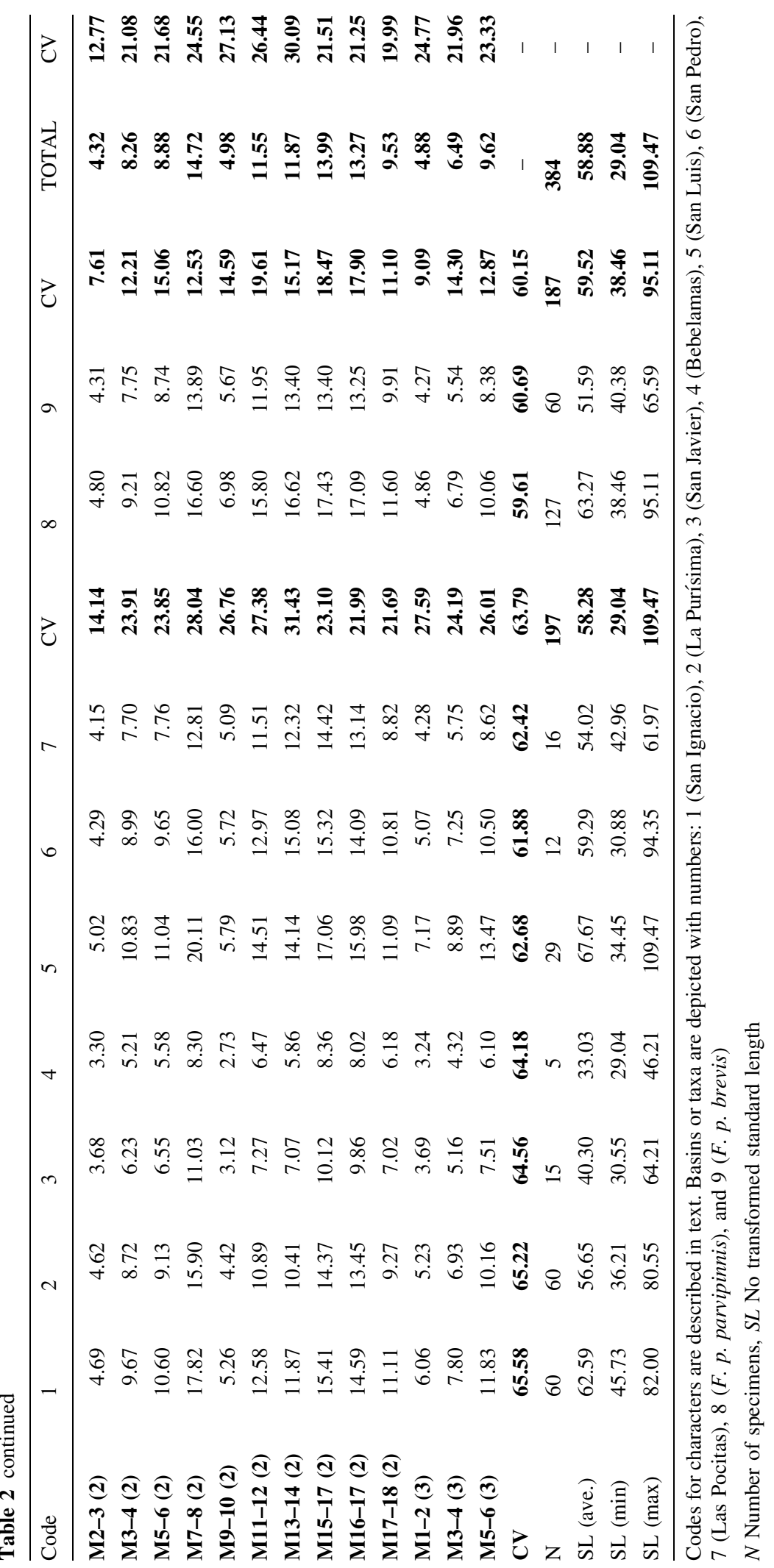



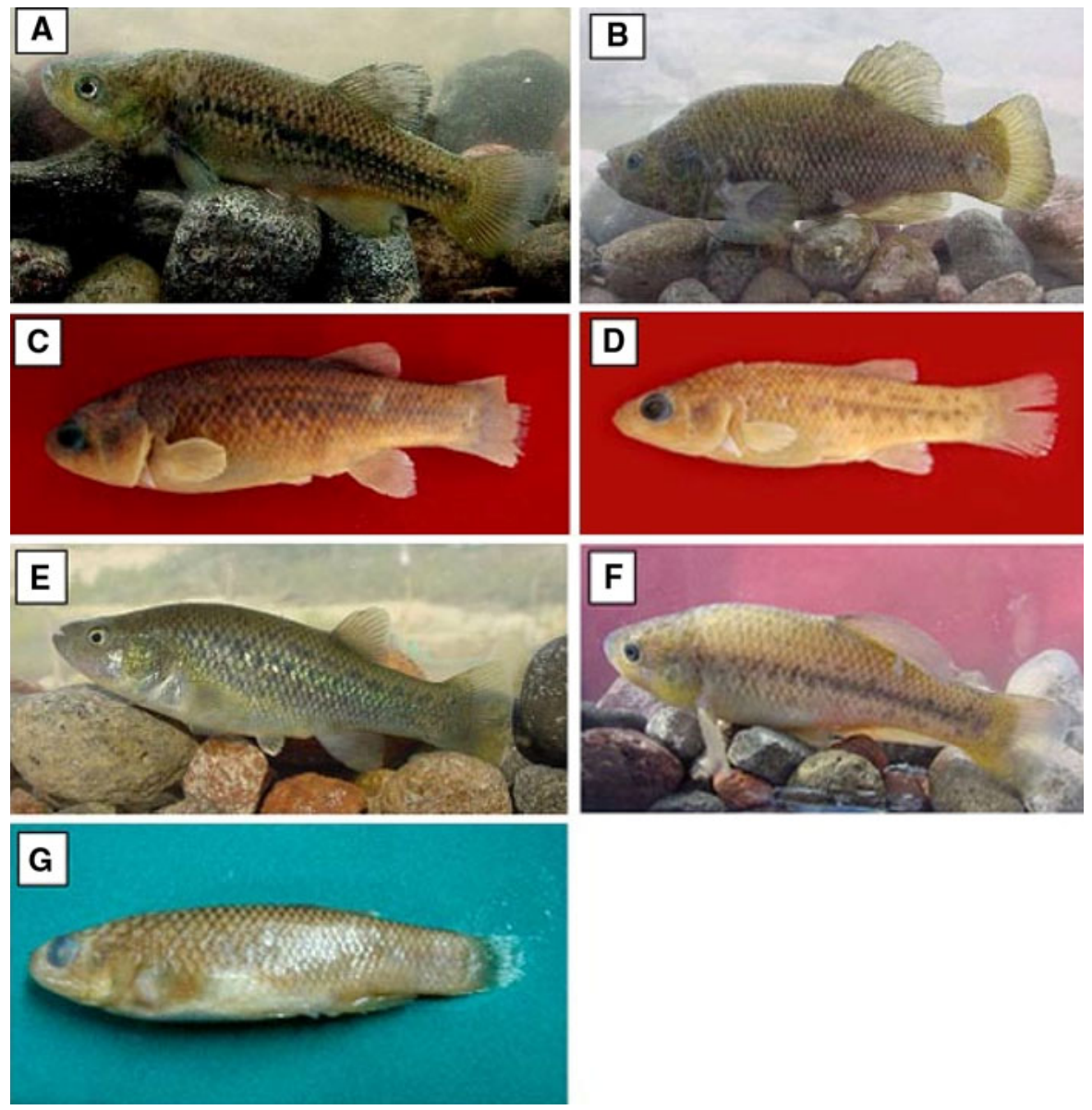

Fig. 3 Specimens of Fundulus lima from different hydrological basins through its distribution range. a San Ignacio, b San Luis, c San Javier, d Bebelamas, e La Purísima, f San Pedro, and g Las Pocitas. Photographs by Gorgonio Ruiz-Campos

F. parvipinnis brevis, (2) association between the northernmost of $F$. lima (Rio San Ignacio basin) with the northern coastal subspecies $F$. parvipinnis parvipinnis, and (3) the intermediate position of the population of $F$. lima from the San Pedro basin in regard to those freshwater (La Purísima basin) and coastal (F. p. brevis) (Fig. 5b).

\section{Final considerations}

The specimens of Fundulus lima examined are representative of the different hydrological basins along its distributional range. Several populations have recently been eliminated due to the introduction of redbelly tilapia (Tilapia $\mathrm{cf}$. zilli) such as those in the oases of San Javier (San Javier Mission), San Luis
Gonzaga (mission and Las Cuedas) and San Pedro de la Presa (Ruiz-Campos et al. 2008).

It is important to mention that our results derived from the comparative morphometric analysis among the three nominal taxa of Fundulus in the Baja California peninsula made it possible to have a broader perspective regarding the inter- and intrapopulation variation of $F$. lima, as well as the identification of diagnostic characteristics to distinguish it from the two coastal subspecies of $F$. parvipinnis (Table 3 ). In a previous morphometric analysis of the genus Fundulus of the Baja California peninsula, Camarena-Rosales et al. (2001) only included one population per taxon, so the interpopulational variation of $F$. lima and its geographic relationship with the coastal subspecies could not be adequately evaluated. Although these authors 


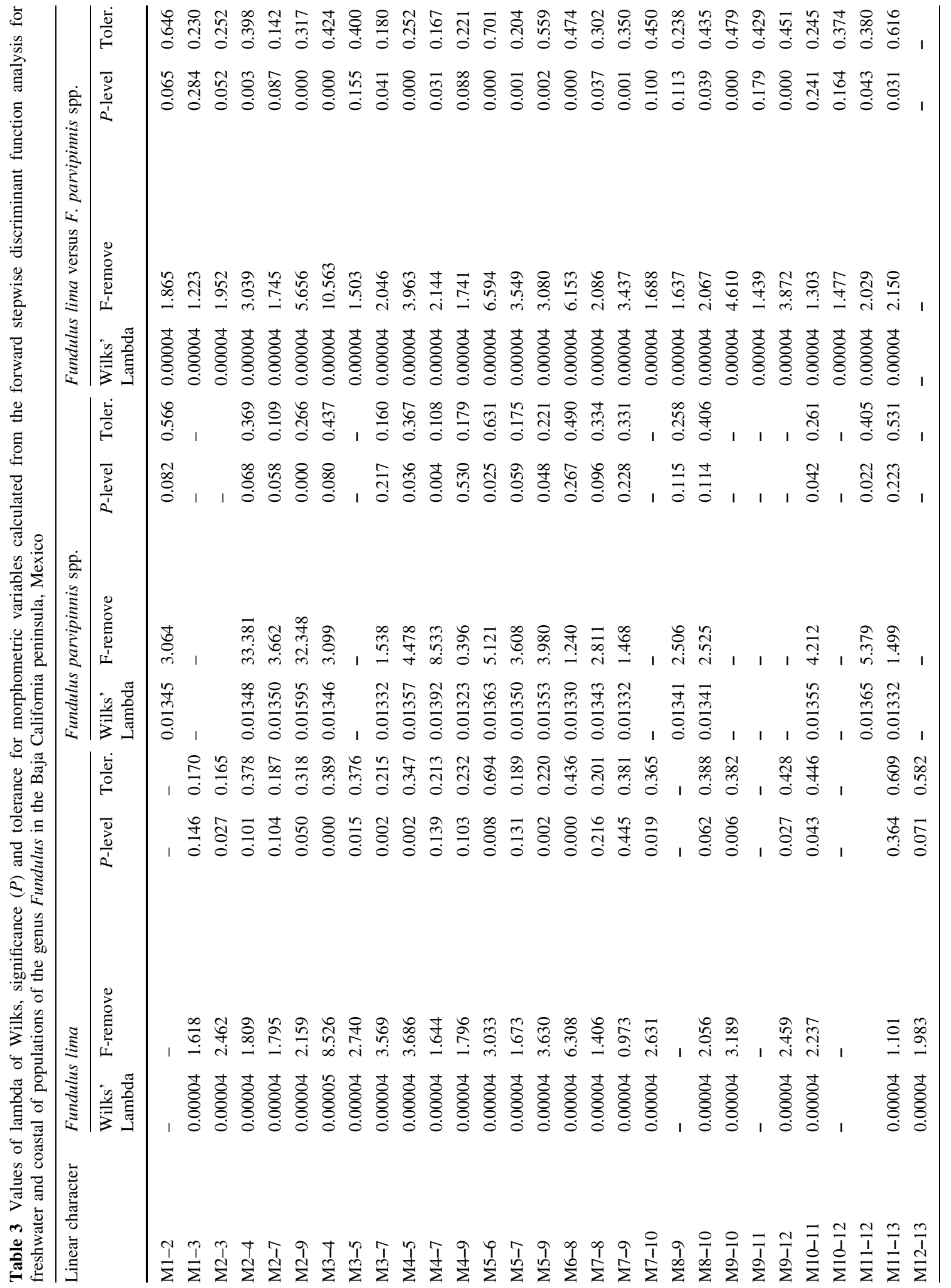




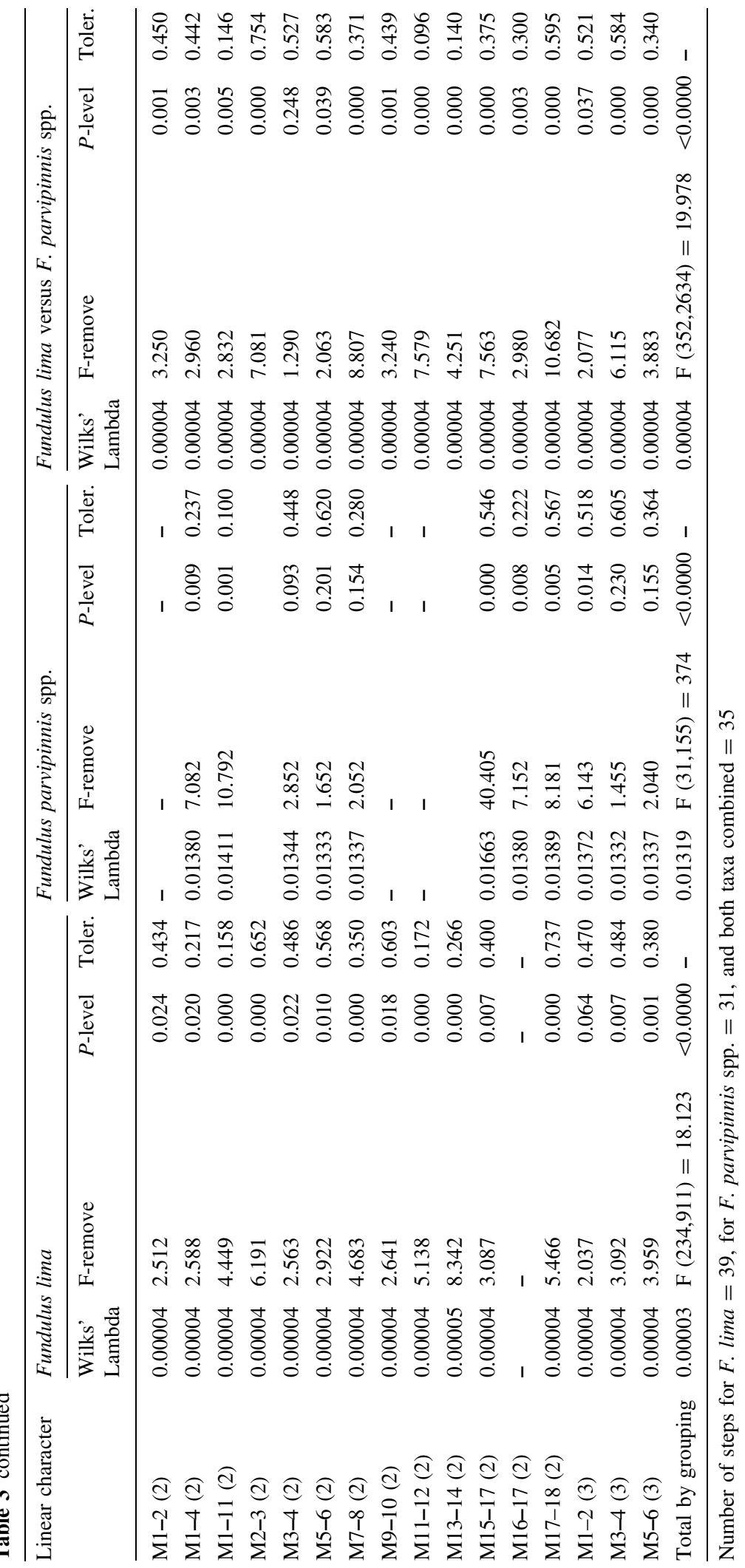


Table 4 Standardized coefficients of the first canonical variables (roots) resulting from the discriminant function analysis for specimens of the genus Fundulus from the Baja California peninsula, Mexico

\begin{tabular}{|c|c|c|c|c|c|c|}
\hline \multirow[t]{2}{*}{ Codes } & \multicolumn{3}{|c|}{ Fundulus lima } & \multirow{2}{*}{$\begin{array}{l}\text { Fundulus parvipinnis spp. } \\
\text { Root } 1\end{array}$} & \multicolumn{2}{|c|}{ Fundulus lima versus $F$. parvipinnis spp. } \\
\hline & Root 1 & Root 2 & Root 3 & & Root 1 & Root 2 \\
\hline M1-2 & - & - & - & -0.19 & -0.03 & -0.14 \\
\hline M1-3 & -0.01 & 0.23 & -0.41 & - & 0.10 & -0.12 \\
\hline M2-3 & -0.12 & -0.55 & 0.03 & & 0.07 & 0.11 \\
\hline M2-4 & -0.24 & 0.28 & -0.17 & -0.24 & 0.21 & -0.37 \\
\hline M2-7 & -0.13 & 0.53 & 0.27 & -0.46 & - & - \\
\hline M2-9 & -0.29 & 0.02 & 0.15 & -0.81 & 0.63 & 0.19 \\
\hline M3-4 & 0.17 & -0.71 & -0.07 & 0.21 & -0.15 & 0.34 \\
\hline M3-5 & -0.13 & 0.08 & -0.52 & & 0.12 & -0.12 \\
\hline M3-7 & 0.26 & 0.42 & 0.24 & 0.25 & -0.09 & -0.37 \\
\hline M4-5 & -0.36 & -0.03 & 0.28 & -0.28 & 0.23 & -0.08 \\
\hline M4-7 & 0.20 & -0.17 & -0.12 & 0.70 & -0.18 & 0.10 \\
\hline M4-9 & -0.22 & -0.34 & -0.15 & -0.12 & - & - \\
\hline M5-6 & 0.02 & -0.08 & -0.19 & 0.23 & -0.10 & 0.25 \\
\hline M5-7 & 0.48 & 0.23 & -0.07 & 0.36 & -0.45 & -0.48 \\
\hline M5-9 & -0.37 & 0.00 & 0.54 & -0.34 & 0.34 & 0.22 \\
\hline M6-8 & -0.19 & -0.21 & 0.50 & -0.13 & 0.23 & 0.29 \\
\hline M7-8 & 0.27 & 0.37 & 0.01 & 0.23 & -0.11 & 0.34 \\
\hline M7-9 & 0.04 & -0.22 & -0.12 & -0.17 & 0.10 & 0.51 \\
\hline M7-10 & 0.06 & -0.10 & -0.51 & & -0.03 & 0.15 \\
\hline M8-9 & - & - & - & 0.25 & -0.07 & -0.24 \\
\hline M8-10 & -0.22 & 0.23 & 0.13 & -0.20 & 0.23 & -0.15 \\
\hline M9-10 & -0.08 & -0.21 & 0.14 & - & 0.04 & -0.20 \\
\hline M9-11 & - & - & - & - & 0.03 & 0.09 \\
\hline M9-12 & -0.29 & -0.12 & -0.23 & - & 0.13 & -0.08 \\
\hline M10-11 & -0.10 & -0.22 & 0.38 & -0.32 & 0.14 & 0.04 \\
\hline M10-12 & - & - & - & - & -0.03 & 0.02 \\
\hline M11-12 & - & - & - & -0.29 & 0.09 & 0.05 \\
\hline M11-13 & -0.09 & -0.01 & 0.11 & -0.14 & 0.18 & $0 .-08$ \\
\hline M12-13 & -0.13 & -0.16 & -0.28 & & & \\
\hline M1-2 (2) & 0.08 & 0.27 & 0.16 & - & 0.01 & -0.16 \\
\hline M1-4 (2) & -0.19 & -0.26 & 0.42 & 0.43 & -0.03 & 0.27 \\
\hline M1-11 (2) & -0.80 & -0.39 & -0.13 & -0.81 & 0.64 & -0.23 \\
\hline M2-3 (2) & -0.04 & 0.14 & 0.18 & & 0.03 & 0.06 \\
\hline M3-4 (2) & 0.10 & 0.20 & -0.43 & -0.20 & -0.03 & -0.10 \\
\hline M5-6 (2) & 0.17 & 0.16 & 0.33 & 0.13 & -0.13 & 0.03 \\
\hline M7-8 (2) & -0.07 & 0.38 & -0.54 & -0.22 & 0.11 & -0.23 \\
\hline M9-10 (2) & -0.21 & -0.29 & -0.03 & - & 0.07 & 0.32 \\
\hline M11-12 (2) & -0.42 & 0.53 & 0.58 & - & 0.30 & -0.80 \\
\hline M13-14 (2) & -0.04 & -0.73 & -0.48 & - & -0.24 & 0.18 \\
\hline M15-17 (2) & -0.41 & -0.23 & 0.22 & -0.62 & 0.44 & 0.43 \\
\hline M16-17 (2) & - & - & - & -0.45 & 0.33 & -0.04 \\
\hline M17-18 (2) & -0.19 & -0.03 & 0.07 & -0.30 & 0.26 & 0.18 \\
\hline M1-2 (3) & 0.17 & -0.15 & 0.26 & 0.27 & -0.12 & 0.01 \\
\hline
\end{tabular}


Table 4 continued

\begin{tabular}{|c|c|c|c|c|c|c|}
\hline \multirow[t]{2}{*}{ Codes } & \multicolumn{3}{|c|}{ Fundulus lima } & \multirow{2}{*}{$\begin{array}{l}\text { Fundulus parvipinnis spp. } \\
\text { Root } 1\end{array}$} & \multicolumn{2}{|c|}{ Fundulus lima versus $F$. parvipinnis spp. } \\
\hline & Root 1 & Root 2 & Root 3 & & Root 1 & Root 2 \\
\hline M3-4 (3) & -0.05 & 0.30 & -0.43 & -0.12 & 0.07 & -0.32 \\
\hline M5-6 (3) & -0.12 & 0.28 & -0.04 & -0.19 & 0.09 & -0.12 \\
\hline Eigenval & 160.20 & 5.99 & 2.62 & 74.80 & 103.37 & 12.66 \\
\hline Cum. Prop & 0.93 & 0.97 & 0.98 & 1.00 & 0.86 & 0.97 \\
\hline
\end{tabular}

See abbreviations of morphometric characters in text

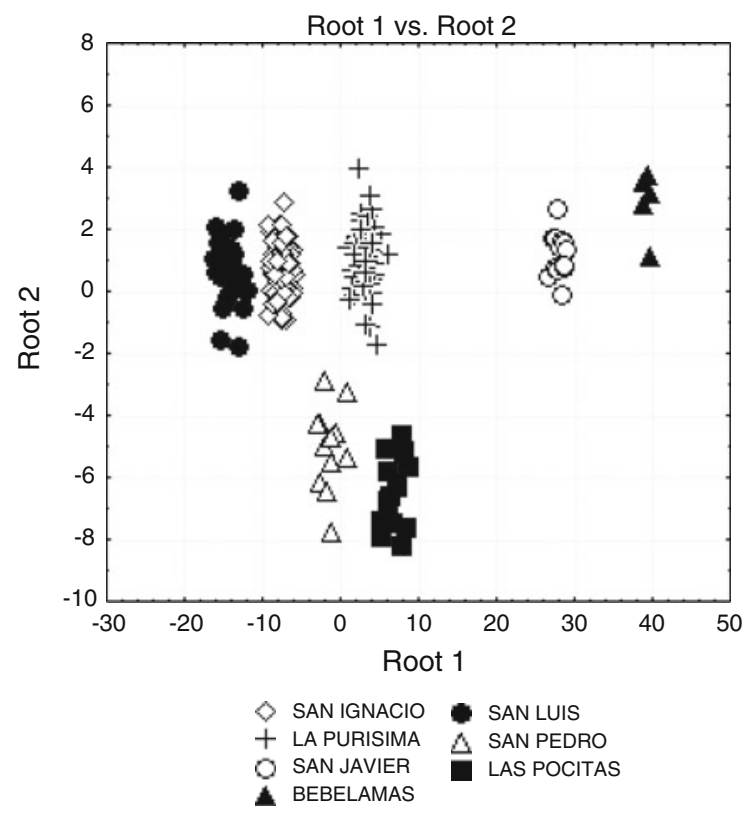

Fig. 4 Classification of individuals based on squared Mahalanobis' distances for populations of Fundulus lima

suggested that F. lima (from San Ignacio oasis) was more closely related to the coastal subspecies F. parvipinnis brevis, our morphometric analyses identified that the southernmost population of $F$. lima (Rio Las Pocitas basin) was in fact more similar to F.p. brevis (Fig. 5). Bernardi et al. (2007) determined, based on an analysis of mitochondrial DNA (D-loop) that the freshwater and coastal populations of Fundulus of the Baja California peninsula seem to form an unresolved trichotomy, which possibly diverged from 200,000 to 400,000 years ago, for this reason each branch could represent a distinct evolutionary unit. Bernardi et al. (op. cit.) also determined that the two coastal subspecies of $F$. parvipinnis are separate from the genetic point of view, between the northern and southern ends of Punta Eugenia
(B.C.S.). These same authors suggest a greater affinity between $F$. p. brevis from Puerto San Carlos and La Bocana with the population of $F$. lima from Río San Pedro basin. This last relationship could be explained by two possible scenarios: 1) a recent episode of invasion by F. p. brevis into the San Pedro and Las Pocitas rivers, and 2) the possible existence of hybridization between $F$. lima and $F$. parvipinnis brevis (Bernardi et al. 2007), an observation that may be consistent with the mis-assignments based on morphological characteristics mentioned above.

At the level of populations of $F$. lima, the segregation of individuals of the Bebelamas and San Javier oases from the rest of the populations is noteworthy, in the measurements of at least 16 somatic characteristics (cf. Table 3). These differences suggest the distinction of a new freshwater form of the genus Fundulus in the Baja California peninsula, which was first referred to by RuizCampos and Contreras-Balderas (1987) as Fundulus sp. for the San Javier oasis [mission of San Francisco Javier]. Each of the freshwater populations could represent an independent historical colonization via fluvial dispersal by a euryhaline coastal ancestor (Camarena-Rosales et al. 2001).

Comparative meristic and osteological studies of the three taxa of Fundulus from the Baja California peninsula are necessary to support and strengthen the genetic study that suggests the recognition of F. parvipinnis brevis as full species (Bernardi et al. 2007), as well as the presence of three freshwater forms of Fundulus for the Baja California peninsula, the first comprised by the populations of the San Ignacio, La Purísima and San Luis basins; the second by the populations of San Javier and Bebelamas; and the third by the southern population of the San Pedro basin. Finally, the southernmost freshwater population (Rio Las Pocitas) reported as F. lima 
Fig. 5 a Classification of individuals based on squared Mahalanobis' distances for freshwater populations (Fundulus lima) and the two coastal taxa (F. parvipinnis parvipinnis and F.p. brevis) from the Baja California peninsula, Mexico. b Tree diagram resulting from the clustering analysis
A

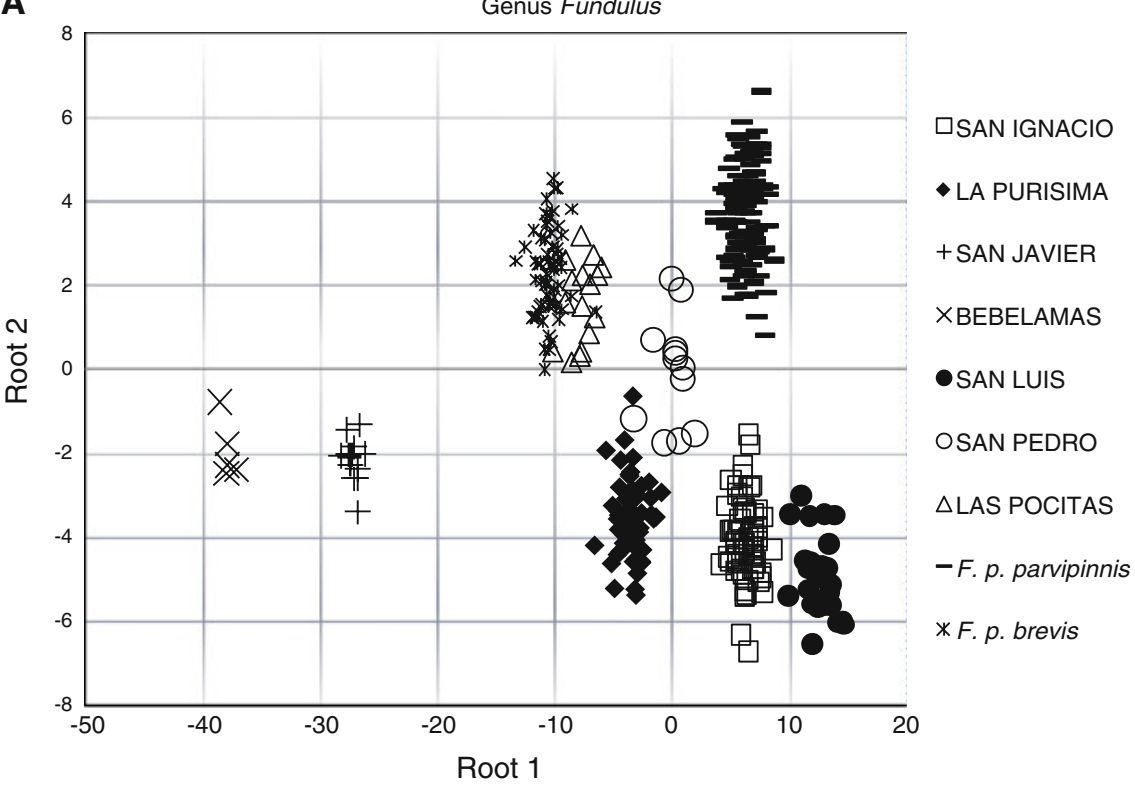

B

Tree Diagram for 9 Variables

Weighted pair-group average

Chebychev distance metric

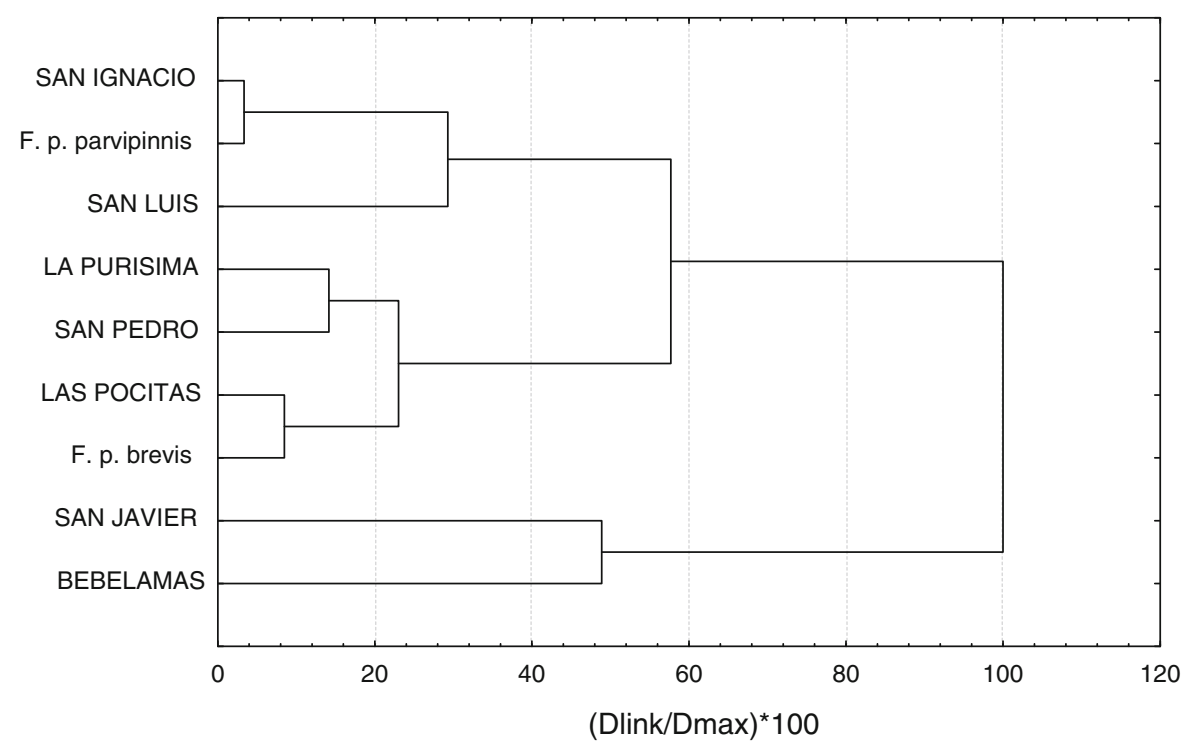

(cf. Ruiz-Campos et al. 2003a, b) should be considered a recent stock derived from the southern coastal killifish, F. parvipinnis brevis.

Acknowledgments Many people participated in the collections of fish specimens from 1977 to 2008. Our thanks go to J.M. Torres, F.J. Viramontes, O. González, F. Reynoso, M.I. Montes, O.M. Tapia, R. Pérez, J. Alaníz, M.E. Valles, A. Gerardo, M.M. Villalobos, F. Camarena, L. Quintana,
J. Escamilla, C. Márquez, A. Valdés, W.R. Zúñiga, V.M. Salceda, A. Gática, J.B. Ortiz, S. Sánchez, A.F. GonzálezAcosta, G. Ruiz Cota, J. De La Cruz, A. Antuna, J.A. Echánove, R. Guzmán, A.G. Jullian, D. Acosta, R. Druck, G. De León, I.A. Peraza, and S. Contreras. This study was funded via Consejo Nacional de Ciencia y Tecnología-Secretaría de Medio Ambiente y Recursos Naturales (grant 2002-CO1-173/ A), Universidad Autónoma de Baja California (grants: DGIP 1275 and DGPI 173) and University of California at Santa Cruz (project US-Mexus No. 2001-SC-0211). JLCA thanks the 
support of the Instituto Politécnico Nacional: COFAA and SEP. We thank the following curators by allowed us to consult and examine specimens of Fundulus in their respective fish collections: Dr. T. Iwamoto and Dr. W.N. Eschmeyer (CAS), Dr. J. De La Cruz-Agüero and Dr. A.F. González-Acosta (CICIMAR-IPN); Dr. S. Contreras-Balderas (deceased), Dra. M. L. Lozano-Vilano and Dra. M. E. García-Ramírez (UANL); and M.Sc. O. Trujillo (UABCS). Thanks to M.E. Reyes-Valdez for processing of Fig. 2. Finally, GRC, FCR and JLCA thank the support of the National System of Researchers of Mexico (CONACyT).

Open Access This article is distributed under the terms of the Creative Commons Attribution Noncommercial License which permits any noncommercial use, distribution, and reproduction in any medium, provided the original author(s) and source are credited.

Appendix 1: Material examined of the genus Fundulus from the Baja California peninsula, Mexico. Numbers of examined specimens are depicted in square brackets

Fundulus lima. Río San Ignacio Basin: oasis San Ignacio between spring and Rancho El Tizón (UABC-1617 [15]), 26-I-2006), Poza Larga (UABC-1312 [8], 15-IV-2002; UABC-1327 [6], 14IV-2002; UABC-1313 [1], 14-IV-2002), Los Corralitos (UABC-1385 [3], 5-II-2003; UABC-1512 [12], 4VII-2004), and San Sabas (UABC-1486 [1], 5-II2003; UABC-1380 [14], 5-II-2003). Río La Purísima Basin: Ojo de Agua (UABC-1463 [1], 12-II2004; UABC-1516 [14], 1-VII-2004; UABC-1383 [6], 8-II-2003; UABC-1384 [4], 8-II-2003), Carambuche [= Cuba] (UABC-758 [8], 15-III-1998), and La Purísima in front of Cerro El Pilón (UABC-1515 [12], 2-VII-2004; UABC-1381 [8], 8-II-2003). Río San Javier Basin: Presa San Javier at San Javier (UANL-2571 [15], 27-IV-1977). Río Bebelamas

Basin: Arroyo Bebelamas at San Lucas [= Poza Honda] (UABC-745 [5], 16-IV-1998). Río San Luis Basin: Arroyo San Luis at Misión de San Luis Gonzaga (UABC-740 [5], 16-IV-1998), Rancho Las Cuedas (UABC-1325 [2], 18-IV-2002; UABC-743 [21], 16-IV-1998), San Basilio (UABC-779 [1], 15V-1998), and Merecuaco (UABC-789 [1], 16-V1998). Río San Pedro Basin: Arroyo San Pedro at San Pedro de La Presa (UABC-1324 [1], 18-IV-2002; UABC-796 [3], 27-VI-1991; CICIMAR-CI 1956 [1], 27-VI-1991; CICIMAR-CI 2023 [1], 24-V-1991),
San Basilio (15), and Pozo del Iritú (UABC-797 [4], 25-VI-1991; CICIMAR-CI 2005 [10], idem). Río Las Pocitas Basin: Arroyo Las Pocitas at El Caracol (UABC-798 [6], 24-V-1991; CICIMAR-CI 2025 [10], idem).

Fundulus parvipinnis parvipinnis. Mouth of Río Cantamar (UABC-479 [6], 23-XI-1996; UABC-437 [3], 21-VIII-1996; UABC-350 [10], 24-II-1995); mouth of Río El Descanso (UABC-478 [10], 22XI-1996; UABC-141 [10], 24-II-1995); mouth of Río La Misión (UABC-978 [10], 1-IX-1995; UABC432 [10], 21-VIII-1996); Bahía Todos Santos [Estero de Punta Banda] at Campo Perinsky (UABC984 [4], 18-III-2000) and Rancho El Refugio (UABC-985 [3], 19-III-2000); mouth of Río San Simón at El Papalote (UABC-316 [10], 27-VI-1996; UABC-587 [10], 8-III-1997); Laguna Guerrero Negro at Estero El Chaparrito (UABC-1600 [10], 7-VIII-2005; UABC-2122 [10], 6-VII-2007); and Laguna Ojo de Liebre at Canal El Rincón del Dátil (UABC-878 [20], 19-I-1997).

Fundulus parvipinnis brevis. Laguna San Ignacio at Campo Kuyima (UABC-1478 [20], 29-III2004; La Bocana: ([10], 14-I-1998); and Bahía Magdalena at Estero San Carlos (UABC-961 [7], 15-I-1997; UABC-1612 [23], 6-VIII-2005).

\section{References}

Arriaga L, Díaz S, Domínguez R, León JL (1997) Composición florística y vegetación. In: Arriaga L, Rodríguez-Estrella R (eds) Los oasis de la Península de Baja California. Publicación No. 13. Centro de Investigaciones Biológicas del Noroeste, La Paz, B.C.S, México, pp 69-106

Bernardi G, Powers DA (1995) Phylogenetic relationships among nine species from the genus Fundulus (Cyprinodontiformes, Fundulidae) inferred from sequences of the cytochrome b gene. Copeia 1995(2):469-473

Bernardi G, Talley D (2000) Genetic evidence for limited dispersal in the coastal California killifish, Fundulus parvipinnis. J Exp Mar Biol Ecol 255:187-199

Bernardi G, Ruiz-Campos G, Camarena-Rosales F (2007) Genetic isolation and evolutionary history of oases populations of the Baja California killifish, Fundulus lima. Conserv Genet 8:547-554

Berra TM (2001) Freshwater fish distribution. Academic Press, San Diego, California, p 604

Bookstein FL, Chernoff B, Elder RL, Humphries JM, Smith GR, Strauss RE (1985) Morphometrics in evolutionary biology: the geometry of size and shape change, with examples from fishes. Special Publication Academy of Natural Science Philadelphia 15:277 
Camarena-Rosales F (1999) Relaciones filogeográficas entre especies y subespecies de Fundulus (Pisces: Fundulidae) de la península de Baja California, México. Tesis Doctoral. Facultad de Ciencias Marinas, Universidad Autónoma de Baja California, México

Camarena-Rosales F, De La Rosa-Vélez J, Ruiz-Campos G, Correa F (2001) Biometric and allozimic characterization of the three coastal and inland killifishes populations (Pisces: Fundulidae) from the Peninsula of Baja California, Mexico. Int Rev Hydrobiol 86:229-240

Castro-Aguirre JL (1978) Catálogo sistemático de los peces marinos que penetran en las aguas continentales de México. con aspectos zoogeográficos y ecológicos, Instituto Nacional de Pesca, México. Serie Científica No. 19, p 298

Castro-Aguirre JL, Espinosa Pérez HS, Schmitter-Soto JJ (1999) Ictiofauna estuarina-lagunar y vicaria de México. Noriega-Limusa, S.A., México, p 711

De la Cruz-Agüero J, Arellano M, Cota VM (1996) Lista sistemática de los peces marinos de las Lagunas Ojo de Liebre y Guerrero Negro, B.C. y B.C.S., Mexico. Ciencias Marinas 22:111-128

Delgadillo J (1992) Florística y ecología del norte de Baja California. Ed. Universidad Autónoma de Baja California. Méxicali, Baja California, México, p 339

Elliott NG, Haskard K, Koslow JA (1995) Morphometric analysis of orange roughy (Hoplostethus atlanticus) off the continental slope of southern Australia. J Fish Biol 46:202-220

Evermann BW (1908) Descriptions of a new species of trout (Salmo nelsoni) and a new cyprinodont (Fundulus meeki) with notes on other fishes from lower California. Proc Biol Soc Wash 21:19-30

Follett WL (1960) The fresh-water fishes: their origins and affinities. Syst Zool 9(3-4):212-232

García-Ramírez ME, Contreras-Balderas S, De Lourdes Lozano-Vilano MA (2006) Fundulis philpisteri sp. nv. (Teleostei: Fundulidae) from the Río San Fernando, Nuevo León, México. In: Lozano-Vilano ML, Contreras-Balderas AJ (eds) Studies of North American desert fishes in honor of E.P. (Phil) pister. Conservationist. Universidad Autónoma de Nuevo León, Monterrey, Mexico, pp 13-19

Hubbs CL, Lagler KF (1958) Fishes of the Great Lakes region. Univesity of Michigan Press, Ann Arbor, p 213

Jolicoeur P (1963) The multivariate generalization of the allometry equation. Biometrics 19:497-499

Mayden RL, Wood RM (1995) Systematics, species concepts, and the evolutionary significant unit in biodiversity and conservation biology. In: Nielsen JL (ed) Evolution and aquatic environment: defining unique units in population conservation. American Fisheries Society Symposium 17, Bethesda, Maryland, pp 58-113

Miller RR, Lea RN (1972) Guide to the coastal marine fishes of California. California Fish and Game, Fish. Bull. 157:1-259
Nelson JS (1994) Fishes of the World, 3rd edn. Wiley \& Sons, New York

Nelson JS (2006) Fishes of the World 4th ed, 4th edn. Wiley \& Sons, New York, p 601

Parenti LR (1981) A Phylogenetic and biogeographic analysis of cyprinodontiform fishes (Teleostei: Atherinomorpha). Bulletin of the American Museum of Natural History 168:341-557

Ruiz-Campos G (2002) Estatus ecológico y distribución de la ictiofauna de humedales costeros (bocanas y marismas) en el noroeste de Baja California México (Área marina prioritaria amenazada A1: Ensenadense). Universidad Autónoma de Baja California. Facultad de Ciencias. Bases de datos SNIB-CONABIO proyecto No. S087. México DF

Ruiz-Campos G (2000) Threatened fishes of the world: Fundulus lima Vaillant, 1894 (Fundulidae). Enviromental Biology of Fishes 59:20

Ruiz-Campos G, Contreras-Balderas S (1987) Ecological and Zoogeographical Check-list of the Continental Fishes of the Baja California Peninsula. Proceedings of the Desert Fishes Council 17:61-69

Ruiz-Campos G, Castro-Aguirre JL, Contreras-Balderas S, Lozano-Vilano ML, González-Acosta AF, Sánchez-Gonzáles S (2003a) An annotated checklist of the freshwater fishes of Baja California Sur, México. Rev Fish Biol Fisheries 12:143-155

Ruiz-Campos G, Camarena-Rosales F, Varela-Romero A, Sánchez-González S, De La Rosa-Vélez J (2003b) Morphometric variation of wild trout populations from northwestern Mexico (Pisces: Salmonidae). Rev Fish Biol Fisheries 13:91-110

Ruiz-Campos G, Camarena-Rosales F, Contreras-Balderas S, Reyes-Valdez CA, De La Cruz-Agïero J, Torres-Balcazar E (2006) Distribution and abundance of the engangered killifish, Fundulus lima (Teleostei: Fundulidae), in oases of central Baja California peninsula, México. Southwest Nat 51:502-509

Ruiz-Campos G, Camarena-Rosales F, Contreras-Balderas S, Bernardi G, De La Cruz-Agüero J (2008) Evaluación ecológica y distribucional de peces exóticos en las regiones hidrológicas de San Ignacio y La Purísima, Baja California Sur, y su impacto en las poblaciones del pez endémico amenazado, Fundulus lima. Informe Final Proyecto SEMARNAT-CONACyT-2002-C01-173

Tamayo JL, West RC (1964) The hydrography of middle America. In: Wauchope IR (ed) Handbook of middle America. University of Texas Press, Austin, pp 84-121

Vaillant ML (1894) Sur une collection de poissons recueillie en Basse-Californie et dans le Golfe par M. Léon Diguet. Bulletin De La Société Philomathique De Paris, ser 3(6):69-75

Wiggins IL (1980) Flora of Baja California. Stanford University Press, Stanford, p 1025 